Haapanen, L., L. Kääntä \& L. Lehti (toim.) 2018. Diskurssintutkimuksen menetelmistä. On the methods in discourse studies. AFinLA-e. Soveltavan kielitieteen tutkimuksia 2018/n:o 11. 156-176.

Lotta Lehti ${ }^{1,2}$ \& Maria Eronen-Valli ${ }^{3}$

${ }^{1}$ Helsingin yliopisto, ${ }^{2}$ Turun yliopisto, ${ }^{3}$ Vaasan yliopisto

\title{
Diskurssintutkimuksen menetelmiä digitaalisen retoriikan tutkimuksessa
}

Digital rhetoric is an emerging field, not yet very known among researchers and students in Finland. The term 'digital rhetoric' refers both to the production of persuasive digital texts and to their analysis. In this paper, we concentrate on the latter, the analysis, and we especially focus on the methods used in studies pertaining to digital rhetoric. Furthermore, instead of reviewing the variety of methods used in digital rhetoric research, we concentrate on how discourse analytic methods can be used in digital rhetoric research. We illustrate some of these uses through examples of studies on two rhetorical concepts in digital communication, namely ethos and argumentation. Our review shows that discourse analytic methods offer useful tools for the study of digital rhetoric.

Keywords: digital rhetoric, discourse analysis, ethos, argumentation Asiasanat: digitaalinen retoriikka, diskurssianalyysi, eetos, argumentaatio 


\section{Johdanto}

Diskurssintutkimus tarjoaa hyödyllisiä menetelmiä retoriikan eli viestinnällä vaikuttamisen tutkimukseen. Retoriikan tutkimuksella on pitkät perinteet: antiikin Kreikasta lähtöisin oleva tieteenala on vuosisatojen kuluessa kehittynyt moniksi suuntauksiksi, joista yksi on digitaalinen retoriikka. Digitaalinen retoriikka terminä on suomenkielisessä tutkimusperinteessä kohtalaisen uusi. Se tarkoittaa sekä viestinnällistä vaikuttamista digitaalisissa ympäristöissä että tällaista vaikuttamista tutkivaa alaa (esim. Zappen 2005; Pfister 2014; Eyman 2015). Tässä artikkelissa keskitytään jälkimmäiseen eli tutkimukseen ja erityisesti sen metodeihin. Digitaaliselle retoriikalle on ominaista monitieteisyys: viestinnän vaikuttamisulottuvuuden kuvaamiseksi hyödynnetään retoriikan teorioiden lisäksi esimerkiksi kielentutkimusta, viestintätieteitä, kulttuurintutkimusta, sosiologiaa ja informaatioteknologiaa. Tässä artikkelissa kuvataan, miten diskurssianalyyttisiä menetelmiä voidaan hyödyntää digitaalisen retoriikan tutkimuksessa. Artikkelissa pohditaan erityisesti sitä, mikä on digitaalisuuden rooli diskurssianalyyttisesti orientoituneessa digitaalisen retoriikan tutkimuksessa.

Artikkeli jakautuu viiteen lukuun. Johdantoa seuraava luku (2) käsittelee retoriikan tutkimuksen ja diskurssianalyysin yhtymäkohtia ja eroja. Tämän jälkeen, luvussa kolme, pureudutaan digitaaliseen retoriikkaan tieteenalana ja kuvataan, miten viestinnän digitaalisuus muokkaa retoriikan tutkimusta. Neljännessä luvussa käsitellään digitaalisen retoriikan tutkimusmenetelmiä ja sen kahdessa alaluvussa valotetaan menetelmien käyttöä kahden retoriikan käsitteen osalta: eetoksen ja argumentaation. Artikkeli päättyy yhteenvetoon, jossa pohditaan uuden tutkimuskohteen ja perinteikkään tieteenalan suhdetta: digitaalisessa retoriikassa sekä sovelletaan aiemmin luotuja teorioita ja menetelmiä digitaaliseen aineistoon että luodaan uusia'.

\section{Retoriikka ja diskurssianalyysi}

Osa tutkijoista näkee retoriikan tutkimuksella ja diskurssianalyysillä olevan yhtäläiset juuret (esim. Johnstone 2002: 232), kun taas toiset painottavat näiden alojen erilaisia kehityskulkuja (esim. Fahnestock 2011: 10). Yhtäläisyyksiä näiden kahden alan välillä on joka tapauksessa havaittavissa: sekä diskurssintutkimus että nykypäivän retoriikan tutkimus nojaavat sosiaaliseen konstruktivismiin teoreettis-metodologisena viitekehyksenään (ks. esim. Pynnönen 2013; Virsu 2012: 30). Molemmat tutkimussuuntaukset korostavat kielenkäytön ja viestinnän roolia ihmisten havainnoiman to-

1 Kiitämme Milla Luodonpää-Mannia ja kahta nimetöntä arvioijaa tarkkanäköisistä ja rakentavista kommenteista. 
dellisuuden rakentumisessa. Eräänlaisiksi diskurssianalyyseiksi voidaankin laskea jo kreikkalaisten sofistien sekä Aristoteleen, Platonin ja heidän seuraajiensa kirjoitukset vaikuttavan puheen pitämisestä. Antiikin Kreikassa puhetaito määriteltiin taidoksi "havaita kunkin asian yhteydessä vakuuttava" (Aristoteles, Retoriikka, 1355b), mikä toimii edelleen retoriikan perustana länsimaisessa koulutuksessa. 1900-luvulla, toisen maailmansodan jälkeen, retoriikan painopiste siirtyi kuitenkin uuden retoriikan myötä puhetaidosta erilaisten vaikuttamaan pyrkivien tekstien kriittiseen tarkasteluun (Perelman \& Olbrechts-Tyteca 1958; Toulmin 1958; Burke 1969). Lisäksi 1900-luvulla retoriikan sovellusala laajeni kaikkeen viestintään, myös sellaiseen, jossa vaikuttaminen ei ole tietoista yleisön suostuttelua (Johnstone 2002: 232-234).

Kun kielioppijärjestelmää korostavan strukturalismin rinnalle nousi funktionaalinen kielentutkimus 1900-luvun puolivälistä alkaen, monia kielentutkijoita ja retoriikan tutkijoita alkoi yhdistää tutkimuskohde eli todelliset kielenkäyttötilanteet ihmisten välisessä viestinnässä. Nimenomaan funktionaalinen kielikäsitys on mahdollistanut retoriikan tutkimuksen ja kielentutkimuksen lähentymisen. Funktionaalinen kielikäsitys tarkoittaa, että "[v]aikka kieli järjestelmänä tietenkin säätelee sitä, mitä ylipäätään voidaan sanoa, on kielen käyttäjällä paljon mahdollisuuksia valita, miten hän järjestelmää käyttää eli miten hän missäkin tilanteessa käyttää kieltä" (Pietikäinen \& Mäntynen 2009: 14). Sekä retoriikan tutkimuksessa että diskurssianalyysissä nähdään kielelliset merkitykset tilannesidonnaisina ja vuorovaikutuksessa syntyvinä. Kielentutkimuksessa yksi ensimmäisistä kielen tilanteista käyttöä korostavista teorioista oli J. L. Austinin (1955) puheaktiteoria, jossa lausumat nähdään kielellisinä tekoina, kuten pyyntöinä, väitteinä, käskyinä tai kutsuina. Lausuman jakaminen lokutiiviseen (propositionaalinen sisältö), illokutiiviseen (lausuman tarkoitus) ja perlokutiiviseen (lausuman aikaansaama reaktio) on hyödyllinen myös retoriikan tarkastelussa. Retoriikan tutkimuksessa keskitytään yleensä illokuutioon eli lausumissa ja teksteissä havaittavien, yleensä varsin epäsuorien, vaikuttamiskeinojen analyysiin. Retoriikan perlokuutiota eli vaikuttamisen tulosta tarkastellaan vaikkapa markkinoinnin alalla brändikartoituksilla tai politiikassa vaalituloksilla.

Retoriikka määritellään nykyisin monella tavalla. Kapeimmillaan retoriikan määritelmä on arkisessa kielenkäytössä, jossa retoriikalla tarkoitetaan usein yleisön manipulointia ja kaunopuheisuutta (ks. esim. Virsu 2012: 32-33, Palonen \& Summa 1996). Laajimmillaan retoriikka puolestaan mielletään "jonkinlaiseksi inhimillistä kokemusta ja tietoa jäsentäväksi ja koko inhimillistä olemassaoloa ja kanssakäymistä tolkullistavaksi prinsiipiksi sekä erottamattomaksi osaksi kielen käyttöä ja kommunikaatiota" (Virsu 2012: 32, ks. myös Foss 1995: 3-4; Watson 1995; Carter \& Jackson 2004; Shotter 1990; Kuyper \& King 2009: 5-6). Oma näkemyksemme retoriikasta asettuu kapean ja laajan näkemyksen välimaastoon - retoriikkaa on kaikessa viestinnässä, ja sen avulla jäsennetään tietoa ja kokemusta, mutta se ei hallitse inhimillistä olemassaoloa. Retoriikka on viestinnällä vaikuttamista, jossa kohtaavat reettori ja yleisö. Reettori-termillä tarkoitamme viestin lähettäjää eli henkilöä, joka tuottaa 
sisältöjä, tai tahoa, joka muuten on vastuussa tuotetusta viestistä. Yleisö puolestaan viittaa viestin vastaanottajaan, joka voi olla sekä tarkoituksenmukainen kohderyhmä että viestin spontaani vastaanottaja. Niin reettori kuin yleisökin voi tarkoittaa yhtä tai useita inmisiä tai organisaatioita. Erityisesti digitaalisissa viestintäympäristöissä korostuu se, että reettori ei ole ainoastaan "puhuja" tai "kirjoittaja" vaan laajemmin sisältöjen tuottaja ja jakaja.

Bizzell ja Herzberg (2001: 15) rinnastavat retoriikan merkitykseen: merkitys ei ole sanoissa itsessään vaan se muodostuu käytössä ja kontekstissa. Kun sanoja käytetään, muodostuu merkityksiä, ja kun muodostuu merkityksiä, syntyy tietoa ja uskomuksia. Tiedon ja uskomusten muodostumisessa on kyse vaikuttamisesta, kun jotkin asiat ja näkökulmat esitetään oikeampina kuin toiset. Retoriikan tutkimuksen tehtävänä on tehdä nämä ideologiset valinnat näkyviksi (Bizzell \& Herzberg 2001: 15). Amossyn (2008) tapaan erotamme viestinnän vaikuttamispyrkimyksen ja vaikuttamisulottuvuuden. Pyrkimyksellä Amossy (2008) tarkoittaa eriävien mielipiteiden vastakkainasettelua ja strategista pyrkimystä toisen ajattelun tai toiminnan muutokseen. Amossyn (mt.) mukaan kohtaamme kuitenkin jatkuvasti kielenkäyttötilanteita, joissa ei ole kyse vaikuttamispyrkimyksistä, mutta niissä on kuitenkin läsnä vaikuttamisulottuvuus. Esimerkiksi arkipäiväinen jutustelu ystävien kesken ei useinkaan sisällä strategista vaikuttamista, mutta sen vaikuttamisulottuvuus piilee keskustelijan tavassa luoda itsestään tietynlaista kuvaa muiden silmissä ja hakea itselleen hyväksyntää. Samoin vaikkapa informaatiopitoinen väitelause tieteellisessä artikkelissa ei tähtää yksinomaan tiedon jakamiseen, vaan sen on myös tarkoitus vaikuttaa lukijan ajatteluun, ymmärtämiseen ja asennoitumiseen. Digitaalisessa retoriikassa analyysi voi kohdistua niin vaikuttamispyrkimykseen kuin -ulottuvuuteenkin.

Amossy (2018: 3) rinnastaa kielenkäytön vaikuttamisulottuvuuden muihin kielenkäytön perusominaisuuksiin kuten subjektiivisuuteen tai dialogisuuteen. Kielenkäytön subjektiivisuudella Amossy (mt.) viittaa siinä näkyviin eksplisiittisiin tai implisiittisiin merkkeihin kielenkäyttäjän asenteista, tunteista tai uskomuksista (ks. Benveniste 1966). Dialogisuus puolestaan viittaa Bahtinin ja hänen kollegoidensa kirjoituksista nousevaan käsitykseen siitä, että kaikessa kielenkäytössä heijastuu ne ilmaisut ja tekstit, joita kielenkäyttäjä on aiemmin vastaanottanut ja tuottanut. Viestintä ei ole yksinäisiä ilmaisuja tyhjyydessä vaan pikemminkin (suullisten ja kirjallisten) tekstien viidakko, jossa eri tekstit ovat tiheästi yhteydessä toisiinsa (ks. esim. Bakhtin 1986). Retoriikan tutkimuksessa on kyse siitä, että kielenkäyttöä tarkastellaan vaikuttamisen näkökulmasta. Kielenkäytön muita perusominaisuuksia ei suinkaan kiistetä, mutta ne eivät ole tutkimuksen ensisijaisena kohteena.

Keskeisintä retoriikan tutkimuksessa on tarkastella reettorin tekemiä valintoja, sillä juuri niissä viestinnällä vaikuttaminen tapahtuu. Reettorin (suullisessa, kirjallisessa, digitaalisessa ja/tai multimodaalisessa) tekstissä tekemiä valintoja tulkitaan suhteessa niiden kantamiin sosiaalisesti jaettuihin merkityksiin. Tässäkin mielessä diskurssianalyysi ja retoriikan tutkimus ovat lähellä toisiaan: molemmat tarkastele- 
vat kielenkäyttöä sosiaalisena toimintana ja jaettuina merkityksinä sekä yhdistävät mikrotason analyysiä makrotason tulkintoihin. Diskurssintutkimuksen piirissä menetelmien kirjo on laaja ja vaihtelee erityisesti sen suhteen, mikä painoarvo yhtäältä mikrotason piirteillä ja toisaalta makrotason kontekstuaalisilla tekijöillä on analyysissä (ks. johdantoartikkeli tässä teemanumerossa). Retoriikan tutkimuksessa hyödynnetään monesti diskurssianalyysin metodeja siten, että diskurssianalyysin tuloksia tarkastellaan ja tulkitaan nimenomaan vaikuttamisen näkökulmasta.

Retoriikan tutkimusta lähimpänä diskurssintutkimuksen kentässä nähdään usein olevan kriittinen diskurssianalyysi (Critical Discourse Analysis, CDA). Sayerin (2006) mukaan kriittiseen diskurssianalyysin kriittisyys tarkoittaa sitä, että se ei tyydy kuvaamaan tutkimuskohdetta, vaan ottaa kantaa kielenkäytön ja hyvinvoinnin (well-being) tai pahoinvoinnin (ill-being) suhteeseen, tarkemmin sanottuna vaikutussuhteeseen. Toisin sanoen se pyrkii tekemään näkyväksi ihmisten välisiä haitallisia valtasuhteita sikäli, kun ne heijastuvat kielenkäyttöön, ja sikäli, kun kielenkäyttö ylläpitää niitä. Samantapainen kantaaottavuus piilee myös retoriikan tutkimuksessa: siihenkään ei kuulu diskurssin suora moraalinen arvostelu, vaikka valtasuhteita paljastetaan. Esimerkiksi Black (1970: 109-110) peräänkuuluttaa, että tutkijoiden olisi tehtävä rohkeasti läpinäkyviksi niitä kielenkäytön keinoja, joilla muun muassa pyritään saavuttamaan valta-asema toisiin ihmisryhmiin nähden. Toisin sanoen tutkijan ei tule olla sokea sille moraaliselle ulottuvuudelle, joka retoriikkaan ja erityisesti sen oletettuihin tai todellisiin vaikutuksiin väistämättä kuuluu. Virsu (2012) näkee diskurssin retorisen analyysin työkaluna, erityisesti niin, että diskurssia tarkastellaan reettorin valitsemina ilmaisutapoina ja merkityksinä. Suhteen voi nähdä myös niin, että retoriikan tutkimus mielletään diskurssianalyysin osa-alueeksi (ks. myös Potter 1996; Virsu 2012: 45). Tässä artikkelissa retoriikan tutkimusta tarkastellaan diskurssianalyysin osa-alueena sikäli, että diskurssianalyysin kenttä tarjoaa metodeja viestinnällisen vaikuttamisen tutkimukseen.

\section{Digitaalisuus ja retoriikka}

Digitaalisen retoriikan juuret juontavat Pohjois-Amerikkaan, erityisesti Yhdysvaltoihin, jossa digitaalinen retoriikka alkoi 2000-luvun alussa vakiintua osaksi opetustarjontaa ja tiettyihin asiantuntijatehtäviin haettiin erikseen digitaalisen retoriikan tutkijoita (Losh 2009: 82). Sana digitaalinen viittaa digitaalisessa retoriikassa ennen kaikkea tutkimuskohteeseen, toisin kuin digitaalisissa ihmistieteissä (digital humanities). Jälkimmäisessä digitaalista on erityisesti tutkimusmenetelmä: esimerkiksi historian, arkeologian, kielitieteen tai taiteentutkimuksen kysymyksiä ratkotaan digitaalisen teknologian mahdollistamilla menetelmillä, kuten tekstinlouhinnalla, muilla koneoppimismenetelmillä tai kuvantamisella. Digitaalisen retoriikan tutki- 
mus sen sijaan tarkastelee digitaalisia aineistoja itse menetelmien digitaalisuuden ollessa toissijaista.

Miten viestinnän digitaalisuus sitten muuttaa retoriikkaa ja miksi on perusteltua puhua tieteenalasta nimeltä digitaalinen retoriikka? Matikainen (2014) tarkastelee digitaalisuuden, käytännössä sosiaalisen median, mukanaan tuomia muutoksia erityisesti organisaatioiden julkisessa viestinnässä. Matikainen (2014) ei käytä termiä 'retoriikka', mutta kyse on pitkälti samojen ilmiöiden tarkastelusta kuin digitaalisessa retoriikassa. Matikaisen (mt.) mukaan digitaalisuus on muuttanut vaikuttamisen prosesseja huomattavasti. Suurin muutos koskee osallistujia: ruohonjuuritason mediakäyttäjät voivat viestiä suoraan organisaatioiden kanssa ja niiden ohi. Tästä johtuen vaikuttaminen on monisuuntaista, eikä viestin lähettäjästä tai vastaanottajasta ole aina selvyyttä. Esimerkiksi markkinoinnin alalla tämä tarkoittaa sitä, että mainonta ei ole enää välttämättä mainostavan organisaation maksamaa mediajulkisuutta (vrt. Malmelin 2003: 20) vaan markkinointiin osallistuvat myös ruohonjuuritason mediakäyttäjät jakamalla mainosviestejä, tykkäämällä niistä tai kirjoittamalla tuotteista esimerkiksi blogikirjoituksia tai arvosteluja. Toisaalta myös organisaatioilla on käytössään uusia mainontakeinoja, kun mainosviestejä voidaan kohdentaa käyttäjille heidän digitaalisen jalanjälkensä perusteella.

Sosiaalisen median alustoilla keskustelua voivat käydä julkisesti lähes kaikki, eikä journalismi näin olleen enää toimi julkisuuden portinvartijana. Konfliktitilanteissa, kuten arabikevään kansannousuissa 2011 tai Ukrainan tapahtumissa 2014, sosiaalinen media toimii paitsi mielipiteiden julkituomisen väylänä myös tiedonvälittäjänä journalistisen median rinnalla. Vuonna 2017 alkanut seksuaalista häirintää vastustava ja näkyväksi tekevä \#metoo-kampanja muuttaa yhteiskunnan rakenteita: se on vaikuttanut muun muassa poliittisiin nimityksiin ja lainsäädäntöön monissa maissa. Kaiken kaikkiaan digitaalista viestintää luonnehditaan usein verkostomaiseksi (esim. Castells 2000, Seppänen \& Väliverronen 2013, Pfister 2014). Verkostomaisuuden sijaan jotkut tutkijat korostavat "kaikukoppia" tai "kuplia" (esim. Colleoni ym. 2014). Puhutaan myös "henkilökohtaisista yleisöistä" (Schmidt 2014), "henkilökohtaisesta joukkoviestinnästä" (Castells 2009), "kytköksisyyden kulttuurista" (van Dijck 2013) ja "konvergenssikulttuurista" (Jenkins 2006). Näiden käsitteiden avulla kuvataan, eri näkökulmia painottaen, digitaalisen murroksen mukanaan tuomia muutoksia julkisessa viestinnässä.

Viestinnän tason muutosten lisäksi myös retoriikan tutkijoiden pääasiallinen tutkimuskohde, teksti, saa uusia muotoja digitaalisessa ympäristössä. Perinteinen kirjallinen tai suullinen teksti ymmärretään yleensä merkityskokonaisuudeksi, joka on jollain tapaa koherentti (ks. esim. Halliday \& Hasan 1976: 1-2). Teksti voidaan mieltää myös diskurssin ilmenemisen muotona tai, kuten Adam (1999: 39) suhteen ilmaisee, diskurssi on tekstin sijoittamista kontekstiinsa. Digitaalisessa viestintäympäristössä teksti voi olla moniaistillinen eli "multimodaalinen" eli siinä voi yhdistyä visuaalista, auditiivista ja tekstuaalista viestintää. Tekstin rajat voivat myös olla en- 
tistä häilyvämpiä, teksti voi olla vuorovaikutuksessa jatkuvasti uudelleen muokkautuva ja lisäksi teksti voi olla kokonaan tai osin koneen tuottamaa. (Eyman 2015; ks. myös Johnson-Ilola 2010). Myös hypertekstin piirteet eli linkit toisiin teksteihin asettavat uudenlaisia haasteita tekstien retoriselle analyysille. Viitattaessa digitaalisen viestinnän ilmenemismuotoihin puhutaankin usein tekstin sijaan performanssista. Digitaalisen retoriikan tutkimuksessa tarkoituksena on kuvata edellä määriteltyä muuttunutta viestintäympäristöä. Zappen (2005) jakaa digitaalisen retoriikan tutkimusalana neljään osa-alueeseen:

- retoristen strategioiden käyttö ja analysointi digitaalisissa teksteissä,

- $\quad$ uuden median ominaispiirteiden, käyttömahdollisuuksien ja rajoitusten havainnoiminen,

- digitaalisten identiteettien muodostuminen ja

- digitaalisten yhteisöjen rakentaminen.

Eyman (2015: luku II) yhtyy Zappenin näkemykseen, mutta lisää listaan neljä osa-aluetta:

- teknologian retoriikan tutkimus,

- ideologioiden ja kulttuuristen vaikutteiden retorinen tutkimus digitaalisessa ympäristössä,

- verkkojen retoristen vaikutusten tutkimus ja

- tekijyyden käsitteistäminen niin ohjelmistojen kuin ihmistenkin osalta.

Nämä kahdeksan osa-aluetta ovat pitkälti samoja, joihin diskurssianalyysin piirissä tehtävä digitaalisen viestinnän tutkimus kohdistuu. Diskurssianalyysin alalla on myös alettu puhua digitaalisen diskurssin analyysistä omana tieteenhaaranaan (Helasvuo ym. 2014). Gredel (2017: 105) toteaa, että digitaalisen diskurssin analyysin ydintä on digitaalisen viestintävälineen (laitteet ja ohjelmistot) huomioiminen. Esimerkiksi sosiaalisen median palvelut, kuten Facebook, Twitter tai blogialustat, tuovat diskurssin analyysiin uusia huomioitavia piirteitä perinteisten kontekstuaalisten seikkojen, kuten osallistujaroolien, instituutioiden vaikutuksen ja yhteiskunnallisen tilanteen lisäksi. Viestintävälineet ovat toki aiemminkin olleet osa diskurssia ja sen analyysiä, mutta digitaalisen murroksen myötä huomiota on kiinnitettävä yhä enemmän viestintävälineisiin. Digitaalisen diskurssin analyysi tuottaa tärkeää tietoa digitaalisen retoriikan tutkimukselle, ja ero näiden kahden nousevan tutkimusalan välillä on häilyvä. Erotuksena digitaalisen diskurssin tutkimuksiin digitaalisen retoriikan tutkimuksissa on aina jollain tapaa läsnä retoriikan käsitteistö ja merkityksenannon vaikuttamisulottuvuus.

Edellä listattujen digitaalisen retoriikan osa-alueiden (Zappen 2005; Eyman 2015) tutkimuksen myötä on nimetty ainakin kaksi digitaaliselle retoriikalle ominais- 
ta viestintätapaa: proseduraalinen retoriikka ja itseilmaisullinen retoriikka. Bogost (2007: 2-3) määrittelee proseduraalisen retoriikan käytännöksi, jossa ohjelmistojen toteuttamia prosesseja käytetään suostutteluun. Tällaiset prosessit ovat ohjelmaan koodattuja toimintoja, jotka avautuvat käyttäjälle vasta hänen omien valintojensa kautta. Proseduraalista retoriikkaa on kaikkialla, missä tietokoneohjelmat suosittelevat käyttäjille aiheita ja sisältöjä: digitaalisissa peleissä, hakukoneissa, sosiaalisen median uutissyötteissä ja käyttäjille kohdistetuissa verkon mainoksissa. Esimerkiksi peleissä proseduraalinen retoriikka toteutuu siinä, että vaikka käyttäjä ei ole täysin vapaa toimimaan itseohjautuvasti, hän pystyy omalla toiminnallaan vaikuttamaan siihen, mitkä peliin etukäteen ohjelmoiduista vaihtoehdoista lopulta aktivoituvat. Käyttäjän toimintaa siis samalla rajoitetaan ja mahdollistetaan antamalla tälle vapaus valita tarjolla olevista vaihtoehdoista mieleisensä. Jokainen käyttäjän tekemä valinta vaikuttaa siihen, millainen näkymä tälle avautuu.

Toinen esimerkki proseduraalisesta retoriikasta on Googlen hakukone. Hakukoneen antamat tulokset tuntuvat niin luonnollisilta, ettei niiden taustalla olevia kaupallisia motiiveja useinkaan huomaa. Käyttäjä on vapaa tekemään omia valintoja avautuvan näkymän pohjalta mutta ei ole välttämättä täysin tietoinen siitä järjestyksestä, jonka mukaan valintavaihtoehdot avautuvat hänen digilaitteensa näytölle. Google nimittäin näyttää ensimmäisinä hakutuloksina tyypillisesti mainostajien maksettuja linkkejä, jotka ovat erehdyttävästi samannäköisiä kuin ei-kaupalliset sisällöt (Brock \& Shepherd 2016: 22). Proseduraalisen retoriikan tutkimisessa aktivoituu moni yllä mainituista kahdeksasta digitaalisen retoriikan osa-alueesta. Erityisesti kyse on tekijyyden (ohjelmistot ja niiden suunnittelijat, sisällöntuottajat, viestivien organisaatioiden vastuuhenkilöt jne.), teknologian ja verkkojen retoriikan ja uuden median piirteiden tutkimuksesta.

Itseilmaisullinen retoriikka puolestaan tarkoittaa yksilön subjektiivista näkökulmaa edustavia, arvottavia mediasisältöjä eli kuvia, tekstejä ja videoita, joilla sekä ilmaistaan oma kanta että pyritään vaikuttamaan muiden mielipiteisiin (ks. Eronen 2015: 1-2, 10). Itseilmaisu ei ole uusi ilmiö: ihmiset ovat aina ilmaisseet näkökantojaan toisilleen. Uutta on, että ruohonjuuritason arkipäiväisistä mielipiteen ilmaisuista on tullut digitaalisen viestintäteknologian myötä julkisia, ja ne voivat levitä nopeasti internetin media-alustoilla tuntemattomille yleisöille. Sisältöjen tuottaminen verkkosivuille ja näkyvyyden saaminen sitä kautta onnistuu ilman suuria taloudellisia uhrauksia tai organisaation suomaa statusta.

Vaikka itseilmaisut ovat mediakäyttäjän oman näkökulman esilletuontia, niiden kautta myös koetaan yhteenkuuluvuutta eli rakennetaan yhteisöä, koska ne perustuvat kulttuurisesti jaettuihin merkityksiin. Itseilmaisullinen retoriikka voi johtaa myös samanmielisyyden vaatimukseen digitaalisissa yhteisöissä, sillä useissa yhteisöissä tavoitellaan samoin ajattelevien hyväksyntää ja halutaan erottautua toisin ajattelevista. (ks. Eronen 2015: 1) Näin yhteisö vahvistuu ja mielipiteet kärjistyvät, mikä voi johtaa esimerkiksi vihapuheeseen. Lisäksi itseilmaisullista retoriikkaa 
käytetään tehokeinona organisaatioiden viestinnässä ja markkinoinnissa. Esimerkiksi henkilökohtaisella äänellä sosiaalisessa mediassa viestivät työntekijät toimivat työnantajansa lähettiläinä - tai organisaatio voi jopa palkata astroturffaajia eli hämäystarkoituksessa yksityishenkilöinä esiintyviä organisaation asian kannattajia (ks. Sihvonen \& Lehti 2018). Itseilmaisullisen retoriikan tutkimuksessa aktivoituu yllä listatuista digitaalisen retoriikan osa-alueista erityisesti retoristen strategioiden ja uuden median piirteiden analyysi, digitaalisten identiteettien ja yhteisöjen tutkimus sekä ideologioiden ja kulttuuristen vaikutteiden tutkimus.

Keskustelu digitaalisen retoriikan sisällöstä ja sovellusalasta käy kiivaana, ja koko nimityskin voidaan kyseenalaistaa (ks. esim. Eyman 2016). Onko perusteltua nimetä uusi tieteenala, jos kyse on lähinnä uudesta tutkimuskohteesta? Eyman (2015: luku I) näkee digitaalisen retoriikan tutkimusalan nimeämisen tarpeellisena kolmesta syystä: se mahdollistaa aiempaa monitieteisemmän retoriikan tutkimuksen, voimistaa retoriikan teorioiden ja metodien uudelleenarviointia sekä selventää digitaalisen retoriikan tutkijoiden paikkaa tiedeyhteisössä. Juuri näistä syistä myös tässä artikkelissa digitaalinen retoriikka tutkimusalan nimenä nähdään mielekkäänä valintana. Siirrymme seuraavaksi tarkastelemaan digitaalisen retoriikan tutkimusmenetelmiä ja erityisesti diskurssianalyysin roolia niissä.

\section{Diskurssianalyysi digitaalisen retoriikan tutkimusmenetelmien joukossa}

Eyman (2015: luku III) luettelee digitaalisessa retoriikassa käytettäviä tutkimusmenetelmiä. Näihin kuuluu digitaaliseen teknologiaan nojaavia menetelmiä, joilla saadaan tietoa tekstiä ympäröivistä seikoista, kuten kytköksistä toisiin teksteihin ja tekstin leviämisestä, mutta jotka eivät ole peräisin retoriikan tutkimuksen piiristä, vaan niitä on alettu hyödyntää digitaalisen retoriikan tutkimuksessa vasta viime vuosina. Tällaisia ovat esimerkiksi datan visualisointi, määrällinen sisällönanalyysi ja hypertekstin verkostoanalyysi (Hypertext Network Analysis (HNA)). Laadullisia ja retoriikan perinteistä kumpuavia menetelmiä luetellessaan Eyman (2015: luku III) mainitsee kattotermeinä lähi- ja etäluvun (close and distant reading), kirjoittamisen tutkimuksen menetelmät ja digitaalisen kirjoittamisen tutkimuksen. Lähiluku tarkoittaa teoriaan nojaavaa tarkkaa tekstin tarkastelua, jolla pyritään syvään merkityksen ymmärtämiseen (Eyman 2015: luku III; ks. myös Brummett 2010). Etäluku puolestaan mahdollistaa Eymanin (mt.) mukaan tekstiä pienempien (esim. teemat ja troopit) tai tekstiä suurempien (esim. genret ja systeemit) yksiköiden analyysin (ks. myös Moretti 2000) ja vaatii koneellisia analyysityökaluja. Diskurssianalyysi mainitaan ainoastaan sivuhuomautuksena digitaalisen kirjoittamisen tutkimuksen yhteydessä. Eyman mainitsee kuitenkin kirjoittamisen tutkimuksen yhteydessä erikseen tärkeänä me- 
netelmänä genreanalyysin ja käsittelee genreä nimenomaan diskurssintutkimuksen sille antamassa merkityksessä (vrt. esim. Pietikäinen \& Mäntynen 2009: 80-87).

Jos diskurssianalyysin menetelmiä tarkastellaan suhteessa aineiston lähi- tai etälukuun, kyse voi olla molemmista. Lähiluvussa tarkasteltavia kielellisiä tai visuaalisia piirteitä ei ole ennalta tarkkaan määritelty, vaan tutkimus perustuu tekstin kokonaisvaltaiseen teoriaan pohjautuvaan analyysiin. Etäluvussa taas tekstiä ei tarkastella kokonaisuutena vaan siitä etsitään ennalta sovittuja piirteitä. Jälkimmäisessäkin lähestymistavassa metodi voi olla hermeneuttinen eli se tarkentuu aineiston analyysin edetessä. Näitä lähestymistapoja voi myös yhdistää. Diskurssianalyyttisesti orientoituneessa digitaalisen retoriikan tutkimuksessa otetaan avuksi diskurssintutkimuksesta kumpuava käsite tai käsitteitä, joka/ jotka operationalisoidaan menetelmäksi kvalitatiiviseen ja/ tai kvantitatiiviseen tarkasteluun. Annamme seuraavassa esimerkkejä digitaalisen retoriikan tutkimusmenetelmistä kahden retoriikan käsitteen - eetoksen ja argumentaation - avulla. Painotamme erityisesti diskurssintutkimuksesta ammentavien menetelmien esittelyä, mutta kuvaamme lyhyesti myös muita menetelmiä, jotta diskurssianalyysin ominaispiirteet tulevat selkeämmin esiin.

\subsection{Eetos}

Eetos tarkoittaa reettorista yleisölle syntyvää vaikutelmaa, jonka reettori pyrkii säätelemään siten, että se suostuttelisi yleisön sitoutumaan viestissä tarjottuihin näkökulmiin tai ylipäätään luottamaan reettoriin. Yleiskielessä käytetään usein termejä imago ja brändi, jotka viittaavat pitkälti samaan asiaan kuin eetos. Toisaalta eetos-termiä käytetään nykyään myös muissa merkityksissä kuin tarkoitettaessa puhujasta muodostuvaa kuvaa. Esimerkiksi 'kotiäitieetos' vaikkapa miespuolisen poliitikon puheessa viittaa diskurssiin, joka heijastaa tiettyä perhepoliittista ideologiaa sen sijaan, että puhujasta muodostuisi kotiäitimäinen kuva. Tässä artikkelissa eetosta käsitellään kuitenkin reettorista syntyvänä vaikutelmana.

Aristoteleen mukaan luotettavan puhujakuvan rakennusaineet ovat erityisesti kokemus ja pätevyys (fronesis), moraalinen hyveellisyys (arete) ja hyväntahtoisuus yleisöä kohtaan (eunoia) (Retoriikka 1378a). Digitaalisen retoriikan moninaisuudessa näiden rinnalle tulee uusia vaatimuksia. On helppo kuvitella tilanteita, joissa pätevän asiantuntijan sijaan ihailua ja luottamusta herättää uusi tulokas tai rivikansalainen - näin on monesti esimerkiksi yhteiskunnallisia asioita koskevissa verkkokeskusteluissa, joissa moni luottaa enemmän kansalaisen omaan kokemukseen perusteluna kuin asiantuntijan esittämään, tutkimukseen nojaavaan, perusteluun. Moraalisen hyveellisyyden edelle saattaa puolestaan mennä vaikkapa karismaattisuus tai hauskuus, kuten monissa YouTube-videoissa. Eetos, kuten kaikki retoriikka, on siis vahvasti kontekstisidonnaista. 
Kun digitaalisen retoriikan tutkimuksissa käsitellään eetosta, menetelmänä on usein lähiluku. Esimerkiksi Lukowski ja Sparby (2017) analysoivat naisten eetosta tietolähteinä imetykseen liittyvillä Wikipedia-sivuilla ja blogikirjoituksissa. Tutkimuksen päätulos on, että naisen eetos, joka muodostuu omien imetyskokemusten kertomisen kautta, ei ole tervetullut Wikipediassa, kun taas äitiysblogeissa naisen eetosta arvostetaan. Metodina mainitaan "retorinen analyysi" (Lukowski \& Sparby 2017: 330) ja tätä toteutetaan eri käsitteiden (esim. episteemisyys ja kairos eli hetkelle otollinen viestintä) avulla, kuvaten miten nämä ilmenevät aineistossa. Luenta on feministinen ja aineiston analyysi sidotaan tiukasti yhteiskunnalliseen tilanteeseen. Analyysi kohdistuu ohjelmistojen (Wikipedia ja blogisivustot) toimintoihin, Wikipedia-määritelmien päivityshistoriaan ja itse teksteihin. Tekstien analyysi kohdistuu pikemminkin tekstin sisältöön kuin kielellisiin piirteisiin.

Eetosta voidaan kuitenkin tutkia myös diskurssianalyysin keinoin ja kiinnittäen enemmän huomiota kielellisiin valintoihin. Esimerkiksi Lehti (2013) on kuvannut eetoksen syntyvän reettorin kielellisistä ja muista valinnoista, jotka tulevat merkityksellisiksi jonkin kategorian sisällä - toisin sanoen viestijän tyylistä (ks. Enkvist 1978 [1964]; Rabatel 2007). Jos esimerkiksi runoa verrataan käyttöohjeeseen, huomio kiinnittyy kahden kategorian, tässä tapauksessa kahden genren, eroihin. Jos sen sijaan verrataan kahta runoa keskenään, reettorin tyyli ja sen luoma eetos on helpompi havaita. Kielelliset ja muut valinnat viestinnässä on hyvin laaja tutkimuskohde, joten on joko analysoitava melko pientä aineistoa kokonaisvaltaisesti tai keskityttävä joihinkin piirteisiin.

Eymanin (2015: luku III) mainitsema etäluku soveltuu myös eetoksen analyysiin. Esimerkiksi poliitikkojen blogieetokseen kohdistuvassa analyysissään Lehti ja Laippala (2014) ovat valinneet tutkimuskohteeksi kielenkäytön virallisuuden asteen poliitikkojen blogeissa ja tutkivat tätä etäluvun avulla, joihinkin piirteisiin keskittyen. Tutkimuksessa laajaa ranskankielistä blogiaineistoa käsiteltiin koneellisin menetelmin, jotta siitä saatiin esiin ennalta määritettyjä piirteitä. Etäluvun avulla löytyneitä kiinnostavia tekstejä tai tekstinosia analysoitiin kuitenkin myös tarkemmassa lähiluvussa.

Kielen virallisuuden astetta indikoivien piirteiden käyttö vaikuttaa eetoksen muodostumiseen, sillä kielen virallisuus voi kertoa esimerkiksi siitä, esiintyykö poliitikko nuorten edustajana tai etäisenä auktoriteettina. Perinteisen sosiolingvistiikan ja tietokonevälitteisen kielenkäytön tutkimusten perusteella luokittelukriteereiksi valittiin yhteensä kuusi kielellistä piirrettä: 1) ne-kieltosanan poisjättö, 2) kysymyslauseen muoto, 3) lyhenteet, 4) puhekieliset sanavalinnat, 5) hymiöt ja 6) toisteiset välimerkit. Aineiston analyysi osoittaa yhtäältä, että tutkitut poliitikot ja blogien kommentoijat kirjoittavat blogeissaan keskimäärin melko yleiskielisesti ja välttävät arkista ilmaisua sekä toisaalta, että yksittäisten poliitikkojen kohdalla arkinen eli "puhetyylinen" ilmaisu voi toimia tärkeänä eetoksen rakentajana. Esimerkiksi eräs poliitikoista näyttää pyrkivän esiintymään kotikaupunkinsa nuorison asioiden aja- 
jana, mikä näkyi paitsi käsitellyissä teemoissa myös usein toistuvissa arkisen kielen piirteissä.

Samaan ranskankielisten poliitikkojen blogiaineistoon kohdistuvassa tutkimuksessa Lehti (2012) puolestaan yhdistää ennalta valittujen piirteiden analyysiä (etäluku) ja tekstin kokonaisvaltaista analyysiä (lähiluku). Hän analysoi subjektiivisuuden ilmauksia Kerbrat-Orecchionin (1997 [1980]) esittelemän tyypittelyn mukaisesti. Ilmauksia ei kuitenkaan analysoida koko aineistosta vaan muiden kriteerien perusteella valitusta suppeasta otannasta. Otannan tekstit analysoitiin kokonaisvaltaisesti kiinnittäen kuitenkin erityistä huomiota Kerbrat-Orecchionin (mt.) luokittelemiin subjektiivisuuden ilmauksiin, kuten adjektiiveihin, persoonapronomineihin ja modaalisuuden merkkeihin tai näiden puuttumiseen. Näiden lisäksi huomioidaan muun muassa käsitellyt aiheet ja argumentointitavat. Analyysin tulokset piirtävät kuvan poliitikkojen jatkumosta, jonka toisessa päässä on sitoutuneen ja tunteikkaan aktivistin eetos ja toisessa puolestaan analyyttisen etäisen asiantuntijan eetos.

Edellä kuvatuissa poliitikkojen blogeihin kohdistuvissa eetoksen analyyseissä on kyse digitaaliseen aineistoon kohdistuvasta diskurssianalyysistä, jonka tuloksia tulkitaan retoriikan, tässä tapauksessa eetoksen, näkökulmasta. Digitaalisen genren, poliitikon blogin, piirteet otetaan huomioon, mutta käytetyt diskurssia käsittelevät menetelmät soveltuvat yhtä hyvin myös muiden kuin digitaalisten aineistojen tutkimukseen. Digitaalisen eetoksen kuvaamiseksi on kehitetty myös käsitteitä, jotka korostavat digitaalisen viestintävälineen piirteitä. Tilanteissa, joissa osallistujien henkilöys on piilossa, eetos perustuu täysin viestin varaan ja voidaan puhua "statuksettomasta eetoksesta" (Warnick 2004). Näin on esimerkiksi monilla keskustelupalstoilla, joilla viestitään nimimerkillä. Verkkoviestinnän tutkijat ovat myös pohtineet ryhmädynamiikan merkitystä eetoksen muodostumisessa. Gurak (1999) käyttää nimitystä 'ryhmäeetos' viitatessaan ehdottomaan samanmielisyyteen perustuvaan verkkokäyttäytymiseen, jossa luotettavuus perustuu ryhmän luomiin sääntöihin ja sanktioihin. Miller (2001) puolestaan tarkastelee eetosta tilanteissa, joissa ihmisen keskustelukumppanina digitaalisessa ympäristössä on viestejä tuottava kone mutta inminen luulee olevansa vuorovaikutuksessa toisen ihmisen kanssa. Tällaiset tilanteet kertovat siitä, miten nopeasti ja alitajuisesti alamme muodostaa käsitystä vuorovaikutuskumppanimme persoonallisuudesta, vaikka emme näe häntä. Ihmisen ja koneen vuorovaikutuksessa tullaan useimmiten myös tilanteeseen, jossa koneen eetos eli luotettavuus murenee.

Paitsi koneen tuottamien viestien kohdalla, ylipäätään digitaalista eetosta tutkittaessa herää usein kysymys siitä, kuka on todellinen reettori. Vaikka reettori rakentaa kuvaa itsestään, hänen digitaalisessa viestinnässään voi olla mukana myös haamukirjoittajia eli henkilöitä, jotka kirjoittavat päivityksiä hänen puolestaan. Sosiologi Erving Goffmanin (1981) osallistujaroolien jaottelun mukaan viestin tuottaja voi olla esittäjä (animator), tekijä (author) tai toimeksiantaja (principal). Esittäjä on se, joka konkreettisesti tuottaa viestin. Tekijä on se, joka ilmaisee omin sanoin aja- 
tuksiaan, vaikka ilmaisu voi tapahtua esittäjän välityksellä. Esittäjä voi olla sama kuin tekijä, mutta näin ei välttämättä ole. Tekijän ja tästä mahdollisesti erillisen esittäjän taustalla voi vielä lisäksi olla toimeksiantaja, jonka arvoja, ajatuksia ja asemaa tekijä tai esittäjä viestissä tukevat. Kun avustaja kirjoittaa vaikkapa poliitikon nimissä tviitin, blogikirjoituksen tai Facebook-päivityksen, hän yleensä on "vain" esittäjä poliitikon itsensä toimiessa tekijänä. Toimeksiantaja tässä tapauksessa voi olla esimerkiksi poliitikon puolue. Digitaalisessa viestinnässä on yleistynyt myös osallistujarooli, jolle ei löydy vastinetta Goffmanin mallista: identiteettivaras. Erityisen tunnettujen henkilöiden kohdalla identiteettivarkaudet ovat yleisiä, ja yleisöltä vaaditaankin monipuolista medialukutaitoa identiteettivarkaan päivittämän tilin tai profiilin tunnistamiseksi.

\subsection{Argumentaatio}

Keskeinen osa retoriikkaa on mielipiteiden esittäminen ja perusteleminen. Mielipiteiden perusteleminen on vahvasti läsnä myös digitaalisessa retoriikassa esimerkiksi poliittisissa blogeissa, eri alojen asiantuntijoiden tviiteissä tai vaikkapa käyttäjien tuottamissa tuotearvosteluissa. Erityisesti verkkokeskusteluissa esiintyvä mielipiteiden esittäminen ja perusteleminen on herättänyt viime aikoina laajaa yhteiskunnallista keskustelua. Esimerkiksi perustelujen laadusta ja kommenttien sävystä huolestuneet mediatalot ovat lisänneet kommenttiosioihinsa toiminnon, jonka avulla osallistujat arvioivat toistensa kommentteja. Verkossa esitetyt argumentit ovat yksi digitaalisen retoriikan tutkimuskohde. Esittelemme seuraavaksi argumenttien analyysitapoja, jotka edustavat Eymanin (2015: luku III) metodijaottelussa lähilukua. Käsittelemissämme tutkimuksissa argumentit on siis tunnistettu yksitellen ilman koneellisia työkaluja.

Loogisesti pitävän argumentoinnin tunnetuin muoto on syllogismi eli argumentti, jossa tehdään kiistämätön johtopäätös annetuista taustaoletuksista (esim. päätaustaoletus: Kaikki ihmiset ovat kuolevaisia, sivutaustaoletus: Sokrates on ihminen > johtopäätös: Siis Sokrates on kuolevainen). Entymeemaksi nimitetään päättelyketjua, joka muistuttaa syllogismia mutta jossa kaikkia vaiheita ei lausuta ääneen (esim. Sokrates on kuolevainen, koska hän on ihminen). Logiikassa ollaan kiinnostuneita päättelyketjun pitävyydestä, ei niinkään taustaoletusten laadusta, sillä taustaoletusten oletetaan olevan tosia. Syllogismit ovat kuitenkin harvinaisia tosielämässä tapahtuvassa viestinnässä. Dialektiikassa, ja sen perinnettä jatkavassa uudessa retoriikassa, huomio kiinnittyy tosielämässä tapahtuvaan argumentointiin. Tosielämän argumentit ovat usein kiistanalaisia, mikä tarkoittaa, että taustaoletuksina käytetään esimerkiksi mielipiteitä, arvoja ja kokemuksia. Argumenttien kiistanalaisuus pätee erityisesti verkkokeskusteluihin, joissa kommentointi on usein "sekavaa" (messy), kuten Grabill ja Pigg (2012) toteavat. 
Lehti ja Kallio (2017) tutkivat argumentointia sosiaalitoimea koskevan uutisen kommentoinnissa useiden suomalaisten sanomalehtien kommenttipalstoilla vuosien 2010 ja 2011 vaihteessa. Uutinen perustui julkaistuun tutkimukseen sosiaalityöntekijöiden mielipiteistä köyhyyden syistä neljässä eri maassa. Tutkimuksen tulokset olivat monisyiset, mutta uutismediat otsikoivat aiheen vahvasti yksinkertaistaen ja nimittivät suomalaisia sosiaalityöntekijöitä tylyiksi. Lehti ja Kallio (2017) yhdistävät tutkimuksessa retoriikan tutkimuksen diskurssintutkimukseen siten, että tutkimus kohdistuu erityisesti osallistumisen muotoihin, joita tutkitaan diskurssintutkimuksen teorioiden avulla. Lisäksi tutkimuksen tulokset suhteutetaan laajaan yhteiskunnalliseen kontekstiin sosiologisia tutkimuksia hyödyntäen. Varsinainen analyysi puolestaan kohdistuu osallistujien kommenteissaan käyttämiin perusteluihin. Tässä hyödynnetään Waltonin ym. (2008) argumenttiluokittelua, joka nojautuu ennen kaikkea Toulminin (1958) näkemyksiin argumentin rakenteen kuvauksesta mutta on samalla myös argumenttien laaja luokittelu Perelmanin (Perelman \& Olbrechts-Tyteca 1958) tapaan. Walton ym. (2008) esittelevät yhteensä 65 erilaista argumenttirakennetta. Lisäksi argumenttityyppien vakuuttavuuden arvioimiseksi esitetään kriittisiä kysymyksiä.

Lehti ja Kallio (2017) keskittyvät analyysissään kolmeen aineistossa toistuvan argumenttirakenteeseen, joissa perusteluna on oma tai läheisen kokemus, asiakkaiden vastuuttomuus ja kansalliset stereotypiat. Näistä yleisin on oma tai läheisen kokemus. Tämä ei sinänsä ole yllättävää, sillä sosiaalista mediaa leimaavana tekijänä pidetään yleisesti omien kokemusten esiintuontia. Esimerkit 1 ja 2 sanomalehtien verkkosivustojen kommenttipalstoilta kuvaavat, miten omaa kokemusta käytetään perusteluna sosiaalivirkailijoiden tylyydelle:

(1) Kerrankin hyvä tutkimustulos. Itse vahvistan, että asiassa on todellista pohjaa. On tullut muutaman kerran koettua, että sos.apu on kamalanpuoleista. Syyllistämistä asioilla, joille et voi mitään. Omassa tapauksessa tuli potkut työstä ja henkilökunta irtisanottiin.

(2) Henkilökohtaisen yhden käyntikerran ja tuttujen puheiden perusteella tämä on kyllä aivan totta. Sosiaalivirkailija on ikään kuin inkvisiittori, joka sitten lopulta pitkin hampain joustaa hieman ja kirjoittaa pikkaraisen shekin asiakkaalle. Ainakin minulle silloin, kun siellä oli pakko käydä. Toivottavasti ei ikinä enään.

Esimerkkejä 1 ja 2 voidaan tarkastella argumenttirakenteina. Waltonin ym. (2008: 309) luokittelusta löytyy argumentteja vastaava rakenne: tietämiseen perustuva argumentti (argument from position to know). Tämän argumentin rakenne on seuraava:

Päätaustaoletus: Toimija T tuntee asemansa perusteella asioita aihepiiristä A, joka sisältää väitteen V.

Sivutaustaoletus: $T$ väittää, että $\vee$ on totta (tai valetta).

Johtopäätös: V on totta (valetta). 
Rakenteen avulla voidaan kuvata esimerkkien 1 ja 2 argumentit siten, että toimija $T$ on asiakas sosiaalitoimistossa, aihepiiri $A$ on sosiaalityöntekijöiden asenteet ja väite $V$ on se, että nämä asenteet ovat tylyjä. Näin ollen argumenttirakenne esimerkeissä 1 ja 2 on seuraava:

Päätaustaoletus: Asiakas tuntee asemansa perusteella sosiaalityöntekijöiden asenteet, joiden väitetään olevan tylyjä.

Sivutaustaoletus: Asiakas väittää sosiaalityöntekijöiden olevan tylyjä. Johtopäätös: Sosiaalityöntekijät ovat tylyjä.

Argumenttirakennetta voidaan arvioida Waltonin ym. (2008: 309) tarjoamien kriittisten kysymysten avulla:

Onko $T$ asemassa, jossa hän voi tietää onko $V$ totta (tai valhetta)?

Onko $T$ rehellinen (luotettava) toimija?

Väittikö $T$, että $V$ on totta (tai valhetta)?

Ensimmäiseen kysymykseen vastaaminen vaatii omista kokemuksista kertovan kommentoijan aseman pohtimista. Onko asiakas sellaisessa asemassa, että hän voi tuntea sosiaalityöntekijöiden tylyjä asenteita? Tämä riippuu aihepiirin $A$ luonteesta ja onkin aiheellista kysyä, mistä aihepiiristä tutkituissa kommenttiosioissa keskusteltiin. Walton ym. (2008: 88) erottavat asiantuntijatiedon ja kokemuksen perusteluna ja sosiaalityöntekijöiden tylyyttä käsittelevässä kommentoinnissa kyse näyttää olevan jälkimmäisestä, asiakkaiden kokemuksesta. Lehden ja Kallion (2017: 62) mukaan asiakkaiden kokemusta tylystä kohtelusta ei voida kiistää, joskin yleistäminen oman kokemuksen perusteella koko ammattiryhmään on kyseenalaista. Sen sijaan on keskeistä, että alkuperäinen uutinen, tutkimus sosiaalityöntekijöiden käsityksistä köyhyyden syistä, ei suinkaan käsitellyt tylyyden kokemuksia asiakaspalvelutilanteessa. Journalistien valinnat uutisten otsikoinnissa ja itse tekstissä ohjasivat siis sitä, millaiseksi verkkokeskustelu muodostui - kun otsikoissa ja teksteissä toistui sana tyly, keskustelijat kommentoivat juuri "tylyyttä".

Toinen argumenttirakenteen arvioimiseksi annettu kriittinen kysymys koskee toimijan $T$ rehellisyyttä ja luotettavuutta. Lehti ja Kallio (2017: 61-62) toteavat, että tähän on vaikea vastata varmasti. On mahdotonta varmistua kommentoijan henkilöydestä ja siitä, toimiiko hän rehellisesti. Tutkitussa aineistossa suurin osa kommentoijista ei esiinny oikealla nimellä vaan nimimerkillä, eikä kirjoittajien kasvoja ole näkyvissä. Toimija $T$ eli kommentin kirjoittaja voi olla vaikkapa provosoiva trolli tai hän voi liioitella tai valehdella. Kolmas kriittinen kysymys koskee lausuman olemassaoloa. Kysymys on ehkä oleellisempi suullisen argumentoinnin analysoinnissa. Tutkitussa aineistossa tästä ei ole epäselvyyttä: toimija on julkaissut kommenttinsa sanomalehden verkkosivulla, joten väitteen ilmaisemista ei tarvitse kyseenalaistaa. 
Lehti ja Kallio (2017) tulkitsevat argumenttirakenteiden analyysin tuloksia yhteiskunnallisessa kontekstissa erityisesti pohtien keskustelun osallistujia. Tutkituilla palstoilla äänessä on huono-osaisin väestönosa: toimeentulotuen saajat. Toimeentulotukeen yleisesti liittyvä häpeän tunne ei anonyymissä digitaalisessa ympäristössä estä osallistumista julkiseen keskusteluun. Toisaalta keskusteluista näyttivät puuttuvan toimijat, jotka yleensä osallistuvat julkiseen keskusteluun sosiaaliturvasta. Esimerkiksi omaan ammatilliseen asiantuntemukseen vetoavat argumentit loistivat poissaolollaan, joten voidaan päätellä, että sosiaalityöntekijät, tutkijat ja muut sosiaalityön asiantuntijat eivät näyttäneet osallistuvan keskusteluun. Lisäksi analyysi osoittaa journalistisen median olevan tärkeä tiedonlähde ja näkökulmien asettaja myös verkkokeskusteluissa.

Lehden ja Kallion (2017) tutkimus on esimerkki siitä, miten retoriikan - tässä tapauksessa argumentoinnin - teorioita hyödynnetään tutkimuksen kohdistuessa digitaaliseen aineistoon ja pyritään selvittämään vaikuttamisen muotoja digitaalisessa viestintäympäristössä. Diskurssintutkimus on tutkimuksessa mukana osallistumisen muotojen tulkinnassa. Toisenlainen tapa pureutua retoriikan digitaalisuuteen on rakentaa uusi teoria digitaalisuuden ominaispiirteiden ympärille.

Erosen (2013) tutkimus mielipiteiden perustelemisesta verkon julkkisjuorupalstoilla on esimerkki siitä, miten digitaalisen retoriikan ilmiöiden kuvaamiseksi nimetään uusi käsite. Eronen (mt.) nojaa perinteisiin argumentaatioteorioihin (Perelman \& Olbrechts-Tyteca 1958; Toulmin 1958) mutta nimeää aineistossaan esiintyvät argumenttirakenteet digitaaliseksi entymeemaksi. Digitaalinen entymeema on Erosen (2013: 57) mukaan argumentti, jossa on väite, mutta ei johtopäätöstä eikä perusteluja, koska reettori olettaa yleisön löytävän perustelut digitaalisesta kontekstista: linkeistä, teksteistä, kuvista ja videoista. Erosen (2013) tutkimuksen kohteena ovat verkkokeskustelut, joissa aiheena ovat uutiset julkisuuden henkilöiden (Rihanna ja Chris Brown; Matti Nykänen ja Mervi Tapola; Sharon Osbourne ja Megan Hauserman; Martina Aitolehti ja Anne-Mari Berg) harjoittamasta väkivallasta, joten moraalinen tuomitseminen on keskeistä kommenteissa.

Tuomitsemisen analysoimiseksi tutkimuksessa hyödynnetään systeemis-funktionaalista suhtautumisen (appraisal) teoriaa (Martin \& White 2005), jota käytetään usein diskurssianalyyttisissä tutkimuksissa. Suhtautumisen teorian ja erityisesti sen asennoitumis-osan (attitude) avulla saatiin selville, että kommentoijat paitsi arvioivat julkisuuden henkilöitä ihmisinä ja heidän moraaliaan uutisoitujen tekojen perusteella (moraalinen arviointi) myös suhtautuvat heihin kulttuurituotteina (amoraalinen arviointi). Ihmisten moraalinen arviointi tapahtuu erilaisin kielellisin keinoin kuin kulttuurituotteiden amoraalinen arviointi. Ihmisten moraalia arvioidessaan kommentoijat ilmaisevat omia tunnetilojaan (esim. "We need to boycott that ****** of Chris Brown! How could he do that? He is a monster.. Poor Rihanna"). Tunnetilat kohdistuvat julkisuuden henkilöihin ja ne on laukaissut uutisoitu väkivaltainen teko. Amoraalisessa kommentoinnissa puolestaan arvioidaan julkisuuden 
henkilöitä objekteina (esim. "Läski tummuu kun missit nyrkkeilee :))") eikä niinkään ilmaista kommentoijan omaa tunnetilaa, joka kohdistuisi arvioinnin kohteena olevien henkilöiden tekoihin.

Tuomitsemisen ilmaukset toimivat argumentin osina verkkokeskustelussa. Argumentti, digitaalinen entymeema, muodostuu kontekstista löytyvistä vihjeistä. Tärkeitä osia ovat muut kommentit sekä linkitetyt tekstit, kuvat ja videot. Digitaalinen entymeema kuvastaa digitaalisen tekstin, tai performanssin, monimuotoisuutta verkkokeskusteluissa: merkityskokonaisuus syntyy palasista ja yhdistää kirjoitusta, kuvaa ja ääntä. Merkityskokonaisuutta työstää yhteisö, jonka jäseniä yhdistää luottamus ja tunneside, vaikka he viestivät nimimerkin takaa ja todellinen henkilöys on piilossa. Digitaalisen entymeeman ongelmana on, että yleisö voi todellisuudessa löytää kontekstista aivan erilaiset perustelut kuin mitä reettori on tarkoittanut, jolloin yhteisöllisyyden rakentuminen on hataralla pohjalla. Toisaalta joissakin tietyssä, hyvin tiiviissä verkkoyhteisöissä jo pienet diskursiiviset piirteet, kuten tietyt slangisanat, voivat olla yhteisöllisyyden osoittimia eikä perusteluja kommenteille edes etsitä. Näin on esimerkiksi julkkisjuoruihin keskittyvällä ONTD (Oh No They Didn't!) foorumilla (https://ohnotheydidnt.livejournal.com/), jota luonnehtii yleisesti osallistujien ironinen suhtautuminen julkisuuden henkilöihin. Foorumilla laaditaan esimerkiksi listoja "suosituimmista" ja "ihailluista" julkisuuden henkilöistä ironiseen sävyyn: todellisuudessa listat perustuvat ennemminkin julkisuuden henkilöiden näkemiseen turhana kertakäyttöviihteenä. Foorumilla korostuu erityisesti amoraalinen digitaalinen entymeema, siis pelkkää esteettistä makua esiintuova toteamus ilman minkäänlaisia perusteluja. Asiallisesti argumentoidut tai moraalinormeja vakavasti painottavat viestit olisivat foorumilla jopa luotaantyöntäviä. Digitaalisen retoriikan tutkimus vaatii tutkijaltaan näin ollen vahvaa viestintäkontekstin tuntemusta, sillä kielelliset vaikutuskeinot eivät toimi yhdellä sivustolla samoin kuin jollakin toisella.

\section{Yhteenveto}

Olemme kuvanneet tässä artikkelissa digitaalisen retoriikan ja diskurssianalyysin suhdetta ja sitä, miten diskurssianalyysin menetelmiä voidaan hyödyntää digitaalisen retoriikan tutkimuksessa. Katsauksemme nojaa Eymanin (2015) näkemykseen digitaalisen retoriikan metodeista, joita on laaja kirjo lähiluvusta koneellisiin menetelmiin. Olemme hyödyntäneet erityisesti Eymanin (mt.) jakoa lähi- ja etälukuun, mitä olemme soveltaneet diskurssianalyyttisten menetelmien erittelyyn sen mukaan, perustuvatko ne tekstin kokonaisvaltaiseen tulkintaan vai ennalta määriteltyjen piirteiden analyysiin.

Kuvaamamme tutkimusmenetelmät osoittavat, että digitaalisuuden asema retoriikan tutkimuksessa vaihtelee. Joissakin tutkimuksissa digitaalisuus on osa kontekstia, ollen näin osa vaikuttavan kielenkäytön analyysiä. Toisissa tutkimuksis- 
sa digitaalisuus on puolestaan sisäänrakennettu sovellettavaan teoriaan eli se on nostettu käsitteenmuodostuksen keskiöön. Lisäksi katsauksemme osoittaa, että digitaalisen retoriikan tutkimuksissa voidaan paitsi hyödyntää olemassa olevia analyysimenetelmiä ja käsitteitä, myös rakentaa uusia. Suhtautumisen teoria, subjektiivisuuden ilmausten luokittelu tai perinteikkäät argumenttiluokittelut ovat esimerkkejä jo olemassa olevien teorioiden hyödyntämisestä. Ryhmäeetos ja digitaalinen entymeema puolestaan edustavat digitaalisen retoriikan tutkimuksesta kumpuavaa uutta käsitteistöä. Niin perinteistä ammentavalla kuin uutta luovallakin metodiikalla on paikkansa digitaalisen retoriikan tutkimuksessa.

Sosiaalisen median ongelmista, kuten vihapuheen yleistymisestä, on viime aikoina keskusteltu paljon. Digitaalisen retoriikan tutkimus ja opetus voisivat lisätä ymmärrystä verkon vaikutuskeinoista ja auttaa ymmärtämään viestinnän monimuotoisuutta. Ei nimittäin ole olemassa yhtä yhtenäistä verkkokeskustelukulttuuria vaan verkossa pyritään vaikuttamaan monin eri tavoin ja monista syistä. Digitaalisen retoriikan tuntemus voi myös edistää vastuullisempaa viestintää sosiaalisessa mediassa. Kun mahdollisuus julkisesti vaikuttavaan viestintään on lähes jokaisella, vastuulliselta mediakäyttäjältä vaaditaan entistä monipuolisempia taitoja. Näihin sisältyy reettorin roolissa ymmärrys oman viestin mahdollisista vaikutuksista ja kyky eläytyä vastaanottajan asemaan. Yleisön roolissa jokaiselta puolestaan edellytetään kykyä tunnistaa muiden käyttämät vaikuttamiskeinot ja arvioida niitä kriittisesti omissa konteksteissaan.

\section{Kirjallisuus}

Adam, J.-M. 1999. Linguistique textuelle. Des genres de discours aux textes. Paris: Nathan.

Amossy, R. 2008. Argumentation et analyse du discours: perspective théoriques et découpages disciplinaires. Argumentation et Analyse du Discours, 1. https://doi. org/10.4000/aad.200.

Amossy, R. 2018. Introduction: la dimension argumentative du discours - enjeux théoriques et pratiques. Argumentation et Analyse du Discours, 20. https://doi.org/10.4000/ aad. 2560 .

Aristoteles 2012 [1997]. Retoriikka ja runousoppi. Suomentanut P. Hohti \& P. Myllykoski. Helsinki: Gaudeamus.

Austin, J. L. 1955. How to do things with words. Oxford: Clarendon Press.

Bakhtin, M. M. (1986). Speech genres and other late essays. C. Emerson \& M. Holquist (toim.) Kääntänyt V. W. McGee. Austin, TX: University of Texas Press.

Benveniste, É. 1966. Problèmes de la linguistique générale, vol. 1. Paris: Gallimard.

Bizzell, P. \& B. Herzberg 2001. The rhetorical tradition: readings from classical times to the present. Boston, MA: Bedford/St. Martin's.

Black, E. 1970. The second persona. Quarterly Journal of Speech, 56 (2), 109-119. https://doi. org/10.1080/00335637009382992.

Bogost, I. 2007. Persuasive games. The expressive power of videogames. Cambridge, MA: MIT Press. 
Brock, K. \& D. Shepherd 2016. Understanding how algorithms work persuasively through the procedural enthymeme. Computers and Composition, 42, 17-27. https://doi. org/10.1016/j.compcom.2016.08.007.

Brummett, B. 2010. Techniques of close reading. Thousand Oaks, CA: Sage.

Burke, K. 1969. A rhetoric of motives. Los Angeles and London: University of California Press.

Carter, P. \& N. Jackson 2004. For the sake of argument: towards an understanding of rhetoric as process. Journal of Management Studies, 41, 469-491.

Castells, M. 2000. The rise of network society. Oxford: Blackwell.

Castells, M. 2009. Communication power. New York: Oxford University Press.

Colleoni, E., A. Rozza \& A. Arvidsson 2014. Echo chamber or public sphere? Predicting political orientation and measuring political homophily in Twitter using big data. Journal of Communication, 64 (2), 317-332. https://doi.org/10.1111/jcom.12084.

Enkvist, N. E. 1978 [1964]. On defining style: an essay on applied linguistics. Teoksessa J. Spencer (toim.) Linguistics and style. Oxford: Oxford University Press, 1-56.

Eronen, M. 2013. Digital enthymeme: morality, emotions, and materialism in new media participation. Sociedad de la Información, 44, 35-64.

Eronen, M. 2015. Rhetoric of self-expressions in online celebrity gossip. Vaasa: Vaasan yliopisto. https://osuva.uwasa.fi/handle/10024/7274.

Eyman, D. 2015. Digital rhetoric: theory, method, practice. University of Michigan Press. http:// www.digitalculture.org/books/digital-rhetoric/.

Eyman, D. 2016. Looking back and looking forward. Enculturation, 23 (November 2016). http://enculturation.net/looking-back-and-looking-forward.

Fahnestock, J. 2011. Rhetorical style. The uses of language in persuasion. Oxford: Oxford University Press.

Foss, S. K. 1995. Rhetorical criticism. Exploration and practice. Long Grove, IL: Waveland Press.

Goffman, E. 1981. Forms of talk. Oxford: Basil Blackwell.

Grabill, J. T. \& S. Pigg 2012. Messy rhetoric: identity performance as rhetorical agency in online public forums. Rhetoric Society Quarterly, 42 (2), 99-119. https://doi.org/10.108 0/02773945.2012.660369.

Gredel, E. 2017. Digital discourse analysis and Wikipedia: bridging the gap between Foucauldian discourse analysis and digital conversation analysis. Journal of Pragmatics, 115, 99-114. https://doi.org/10.1016/j.pragma.2017.02.010.

Gurak, L. 1999. The promise and the peril of social action in cyberspace: ethos, delivery, and the protests over MarketPlace and the Clipper chip. Teoksessa M. A. Smith \& P. Kollock (toim.) Communities in Cyberspace. London: Routledge, 243-263.

Halliday, M. A. K. \& R. Hasan 1976. Cohesion in English. London: Longman.

Helasvuo, M.-L., M. Johansson \& S.-K. Tanskanen 2014. Johdatus digitaaliseen vuorovaikutukseen. Teoksessa M.-L. Helasvuo, M. Johansson \& S.-K. Tanskanen (toim.) Kieli verkossa. Näkökulmia digitaaliseen vuorovaikutukseen. Helsinki: SKS, 9-28.

Jenkins, H. 2006. Convergence culture. Where old and new media collide. New York \& London: New York University Press.

Johnson-Eilola, J. 2010. Among texts. Teoksessa S. Selber (toim.) Rhetorics and technologies: new directions in writing and communication. Columbia, SC: University of South Carolina Press, 33-55.

Johnstone, B. 2002. Discourse analysis. Oxford: Blackwell.

Kerbrat-Orecchioni, C. 1997 [1980]. L'énonciation: de la subjectivité dans le langage. Paris: Armand Colin.

Kuyper, J. A. \& A. King 2009. What is rhetoric? Teoksessa J. A. Kuyper (toim.) Rhetorical criticism: perspectives in action. Plymouth: Lexington Books, 1-12. 
Lehti, L. 2012. Le blog de politicien: un espace de subjectivité affichée? Argumentation et analyse du discours, 9. https://doi.org/10.4000/aad.1391.

Lehti, L. 2013. Genre et ethos: des voies discursives de la construction d'une image de l'auteur dans les blogs des politiciens. Turku: Turun yliopisto. http://www.utupub.fi/ handle/10024/93657.

Lehti, L. \& J. Kallio 2017. Participation in an online social policy discussion: arguments in focus. Discourse, Context \& Media, 19, 58-65. https://doi.org/10.1016/j. dcm.2017.02.005.

Lehti, L. \& V. Laippala. 2014. Style in French politicians' blogs: degree of formality. Language@ Internet, 11 (1), article 1. URN: nbn:de:0009-7-37980.

Losh, E. 2009. Virtualpolitik. An electronic history of government media-making in a time of war, scandal, disaster, miscommunication, and mistakes. Cambridge, MA: The MIT Press.

Lukowski, A. A. \& E. M. Sparby 2017. Breastfeeding, authority, and genre: women's ethos in wikipedia and blogs. Teoksessa M. Folk \& S. Apostel (toim.) Establishing and evaluating digital ethos and online credibility. Hershey, PA: IGI Global. 329-347.

Malmelin, N. 2003. Mainonnan lukutaito. Mainonnan viestinnällistä luonnetta ymmärtämässä. Helsinki: Gaudeamus.

Martin, J. R. \& P. R. R. White 2005. The language of evaluation. Appraisal in English. New York, NY: Palgrave Macmillan.

Matikainen, J. 2014. Haastettu vaikuttaminen. Teoksessa V. Luoma-Aho (toim.) ProComma Academic: särkymätön viestintä. Helsinki: ProCom - Viestinnän ammattilaiset ry. http://viestijat.fi/haastettu-vaikuttaminen/.

Miller, C. R. 2001. Writing in a culture of simulation: ethos online. Teoksessa P. Coppock (toim.) The semiotics of writing. Transdisciplinary perspectives on the technology of writing. Turnhout, Belgium: Brepols, 253-279.

Moretti, F. 2000. Conjectures on world literature. New Left Review, 1, 54-68. https:// newleftreview.org/II/1/franco-moretti-conjectures-on-world-literature.

Palonen, K. \& H. Summa 1996. Johdanto: retorinen käänne? Teoksessa K. Palonen \& H. Summa (toim.) Pelkkää retoriikkaa. Tutkimuksen ja politiikan retoriikat. Tampere: Vastapaino. 7-19.

Perelman, C. \& L. Olbrechts-Tyteca 1958. Traité de l'argumentation: la nouvelle rhétorique. Bruxelles: Editions de l'université de Bruxelles.

Pfister, D. S. 2014. Networked media, networked rhetorics. Attention and deliberation in the early blogosphere. University Park, Pennsylvania: The Pennsylvania State University Press.

Pietikäinen, S. \& A. Mäntynen. 2009. Kurssi kohti diskurssia. Tampere: Vastapaino.

Potter, J. 1996. Representing reality. Discourse, rhetoric and social construction. London: Sage.

Pynnönen, A. 2013. Diskurssianalyysi: tapa tutkia, tulkita ja olla kriittinen. Jyväskylän yliopiston kauppakorkeakoulun Working Paper N:o 379. Jyväskylä: Jyväskylän yliopisto. https:// jyx.jyu.fi/handle/123456789/42412.

Rabatel, A. 2007. La dialectique du singulier et du social dans les processus de singularisation: style(s), idiolecte, ethos. Pratiques, 135/136, 15-34. https://doi. org/10.3406/prati.2007.2153.

Sayer, A. 2006. Language and significance - or the importance of import: implications for critical discourse analysis. Journal of Language and Politics, 5 (3), 449-471. https://doi. org/10.1075/jlp.5.3.10say.

Schmidt, J.-H. 2014. Twitter and the rise of personal publics. Teoksessa K. Weller, A. Bruns, J. Burgess, M. Mahrt \& C. Puschmann (toim.) Twitter and society. New York, NY: Peter Lang, 3-14. https://doi.org/10.3726/978-1-4539-1170-9.

Seppänen, J. \& E. Väliverronen 2013. Mediayhteiskunta. Tampere: Vastapaino. 
Shotter, J. 1990. The social construction of remembering and forgetting. Teoksessa: D. Middleton \& D. Edwards (toim.) Collective remembering. London: Sage, 120-138. Sihvonen, T. \& L. Lehti 2018. Keinotekoiset kommentit? Astroturffaus digitaalisen vaikuttamisen välineenä. Lähikuva, 31 (2), 10-28. https://doi.org/10.23994/lk.75046.

Toulmin, S. 1958. The uses of argument. Cambridge: Cambridge University Press.

van Dijck, J. 2013. The culture of connectivity: a critical history of social media. Oxford: Oxford University Press.

Virsu, V. 2012. Sitouttamisretoriikka yritysviestinnässä. Turku: Turun yliopisto. http://www. utupub.fi/handle/10024/73970.

Walton, D., C. Reed \& F. Macagno 2008. Argumentation schemes. Cambridge: Cambridge University Press.

Warnick, B. 2004. Online ethos: source credibility in an "authorless" environment. American Behavioral Scientist, 48 (2), 256-265. https://doi.org/10.1177/0002764204267273.

Watson, T. J. 1995. Rhetoric, discourse and argument in organizational sensemaking: a reflexive tale. Organization Studies, 16 (5), 805-821. https://doi.org/10.1177/ 017084069501600503.

Zappen, J. P. 2005. Digital rhetoric: toward an integrated theory. Technical Communication Quarterly, 14 (3), 319-325. https://doi.org/10.1207/s15427625tcq1403_10. 